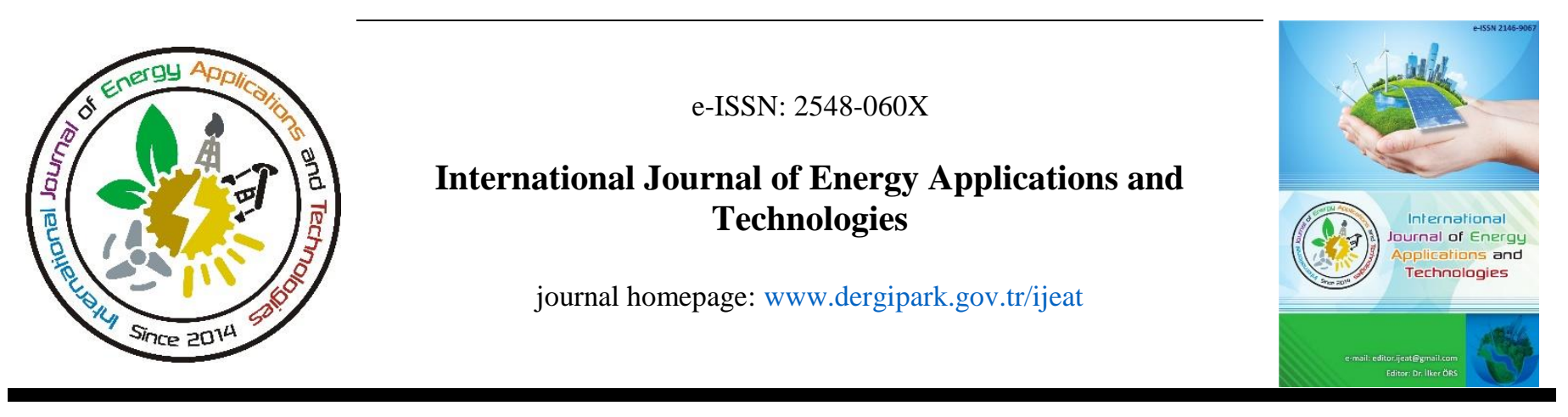

Original Research Article

\title{
As a case study, energy analysis application of a hotel business in private sector
}

\author{
Fatih Aydın $^{1 *}$, Fatma Nur Günay ${ }^{2}$ \\ ${ }^{I}$ Necmettin Erbakan University, Faculty of Engineering, Department of Energy Systems Engineering, Konya, Türkiye \\ ${ }^{2}$ Necmettin Erbakan University, The Graduate School of Natural and Applied Science, Department of Energy Systems Engineering, Konya, Türkiye
}

\author{
ARTICLE INFO \\ * Corresponding author \\ fatihaydin@erbakan.edu.tr \\ Received July 8, 2021 \\ Accepted October 27, 2021 \\ Published by Editorial Board \\ Members of IJEAT \\ (C) This article is distributed by \\ Turk Journal Park System under \\ the CC 4.0 terms and conditions. \\ doi: 10.31593/ijeat.964832
}

\begin{abstract}
In our study, a detailed energy study was carried out in a hotel business, which is a commercial building, energy saving potential was determined, measures that could be taken to increase energy efficiency and reduce energy consumption costs were determined and recommendations were presented. As a result of the measurements of the hot water installation line with the thermal camera, heat losses in the valves and flanges were observed and insulation was recommended. When the investment determined for insulation is made, it is calculated that there will be a decrease of approximately $17 \%$ in the annual energy consumption for the water installation. After heating, booster and fire pump motors with efficiency class $\mathrm{EFF}_{2}$ were replaced with $\mathrm{IE}_{4}$ efficiency motors, it is seen there is a $6.9 \%$ increase in motor efficiency. As a result of replacing the $\mathrm{IE}_{1}$ class engine used in the cooling system with an IE4 class engine, the engine efficiency is expected to increase by $6.2 \%$. As a result of the replacement of halogen bulbs in the business with LED luminaires, the annual total electricity savings were calculated as approximately $19158.12 \mathrm{~kW} /$ year.
\end{abstract}

Keywords: Energy, Energy Audit, Energy Study, Energy Efficiency, Energy Consumption

\section{Introduction}

Basically, energy is the ability to do work. It is one of the fundamental dimensions of physics that cannot be measured directly. It can be determined through the work to be done to change the state of a physical system or by different calculations depending on the type of energy. Energy can be used or generated in different ways. It occurs and is used in the form of, heat, mechanical (kinetic and potential), chemical, electrical, nuclear, magnetic energy. The system can use some or all of these energy forms while performing the work [1]. Energy is required to meet our basic needs such as feeding and warming. In addition to meeting our basic needs, it is an important requirement that must be used in industry and production. In other words, it is defined as 'the ability to make a move' as a consumption tool that directly affects economic development [2].
The common unit of energy is "Ton Equivalent Oil". It is a widely used measurement unit that facilitates common production or calculation processes in different energy types. The reason for the widespread use of TEO is that the primary (coal, oil, etc.) and secondary (electricity, gasoline, etc.) energy resources that are calculated have their own measurement units [1].

The development level of the countries is directly proportional to the energy consumption per capita. To meet the energy consumed, it is necessary to have continuous and sufficient energy resources. Fossil fuels are primarily used throughout the world to meet the energy needs. However, the limited fossil fuel reserves and the depletion prediction led to the search for alternative energy resources. These searches could not reach a sufficient level to meet the current energy need. The limited energy production and the regular rise in 
energy demand increase the importance of energy efficiency [3].

Reducing energy consumption for any need (by isolating houses, increasing engine efficiency, etc.) reduces pollutant emissions automatically and proportionally. Energy efficiency measures are the cheapest way to protect the environment as they are cost-effective and do not require extra costs for environmental protection [4].

Energy saving, on the other hand, refers to the reduction in the amount of energy consumed at each stage to realize a certain amount of production and service as a result of the measures taken by the users in order to make efficient use of energy and energy resources [5].

Energy efficiency is a concept that complements national strategic objectives such as ensuring security of supply in energy, reducing risks arising from external dependency, making energy costs sustainable, protecting the environment and combating climate change $[6,7]$.

The oil crisis has led to the emergence of economic crisis and energy bottleneck all over the world. Countries have started to give importance to the efficient use of energy and the research and development of new energy resources to eliminate the negative effects of this energy crisis on their economies [8].

Focus should be on buildings in an effective strategy to reduce global energy consumption [9]. It is essential to increase the energy efficiency of the building stock for sustainability goals worldwide [10].

Building audits are conducted in many commercial buildings to identify opportunities to reduce energy costs and improve building management. As inspections often require considerable effort by civil engineers to obtain building details, they are often economical for larger commercial building owners [11, 12].

Hwang et al. 2019 [13], aimed to find out in their study how significant energy performance reflecting good energy management and energy saving measures (ECM) can be operated for complex buildings with different systems and for hospital buildings, which is a category that covers large gaps in between. In the end, they concluded that the energy saving of the hospital building is largely required to determine the energy utilization standard of the target facility system and to find the energy saving operating factor according to the characteristics of the medical facility through smart energy analysis of the hospital building.

Balan and Yashvanth 2020 [14], worked on energy auditing in residential buildings. According to the research team's recommendations, a small number of split air conditioning systems were replaced with a central air conditioning unit. In new buildings, the application was easier and the calculations were made at an affordable cost in existing buildings considering the building expenses, and payback period was determined as 4 years with the total implementation cost. Cooling load calculation was made by duct losses with $20 \%$ loss for a central air conditioner. They found that the replacement cost of the new system was much lower than the overall operating cost of existing conventional systems.

This study sets an example for improving efficiency in commercial buildings, which covers an important part of energy efficiency.

\section{Material and Methods}

Our study, under the subject of energy efficiency in buildings which covers a significant part of energy efficiency, includes the examination of the energy consumption and energy management system of the facility, the investigation of the efficiency of existing luminaires, building envelope, heating and cooling systems, air handling units and aspirator units, belt and pulley systems, fan and pump systems, flue gas measurement in boilers, boiler body thermal measurement and calculation of boiler. In the energy studies, the devices calibrated and labeled by accredited national or international organizations were used. Fluke brand Ti 27 model device with 11090481 serial number was used to determine the heat losses in the hotel where the energy audit was performed. The device measures in the standards of AB-0155-K and TS EN ISO / IEC 17025.

Table 1. Technical specifications of thermal imaging device [15]

\begin{tabular}{|c|c|c|}
\hline Property & Unit & Value \\
\hline \multirow{3}{*}{ Temperature } & Operating $\left({ }^{0} \mathrm{C}\right)$ & -10 to 50 \\
\hline & Storage $\left({ }^{0} \mathrm{C}\right)$ & -20 to 50 \\
\hline & Charge $\left({ }^{\circ} \mathrm{C}\right)$ & 0 to 40 \\
\hline Relative Humidity & $\%$ & 10 to 95 \\
\hline \multirow{2}{*}{ Screen } & Backlight (inches) & 3.7 \\
\hline & $\mathrm{LCD}(\mathrm{mm})$ & $640 \times 480$ \\
\hline Software & \multicolumn{2}{|c|}{ Smart View } \\
\hline $\begin{array}{l}\text { Battery Charge } \\
\text { Time }\end{array}$ & Hour & 2.5 \\
\hline Size & $\mathrm{H} \times \mathrm{W} \times \mathrm{L}(\mathrm{cm})$ & $27.7 \times 12.2 \times 17$ \\
\hline Weight & $\mathrm{kg}$ & 1.05 \\
\hline Accuracy & $\begin{array}{l}25{ }^{\circ} \mathrm{C} \text { nominal } \\
\text { value }\end{array}$ & $\pm 2{ }^{\circ} \mathrm{C}$ or $\% 2$ \\
\hline Frequency & $\mathrm{Hz}$ & 9 to 60 \\
\hline Sensor Type & Pixel & $240 \times 180$ \\
\hline Heat Sensitivity & $\begin{array}{l}30^{\circ} \mathrm{C} \text { target } \\
\text { temperature }\end{array}$ & $<0.05$ \\
\hline $\begin{array}{l}\text { Infrared Spectrum } \\
\text { Band }\end{array}$ & $\mu \mathrm{m}$ & 8 to 14 \\
\hline $\begin{array}{l}\text { Minimum Focus } \\
\text { Distance }\end{array}$ & $\mathrm{cm}$ & 46 \\
\hline
\end{tabular}




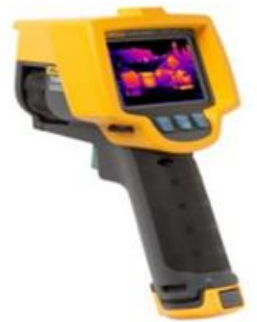

Fig. 1. Thermal imaging device

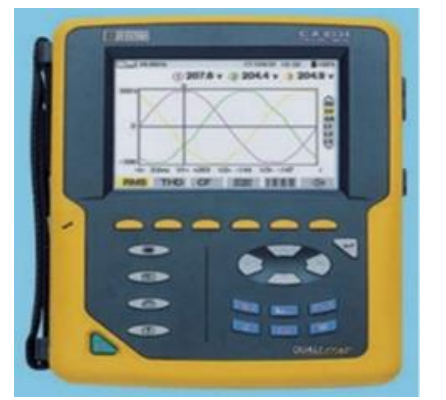

Fig. 2. Three phase portable energy analyzer

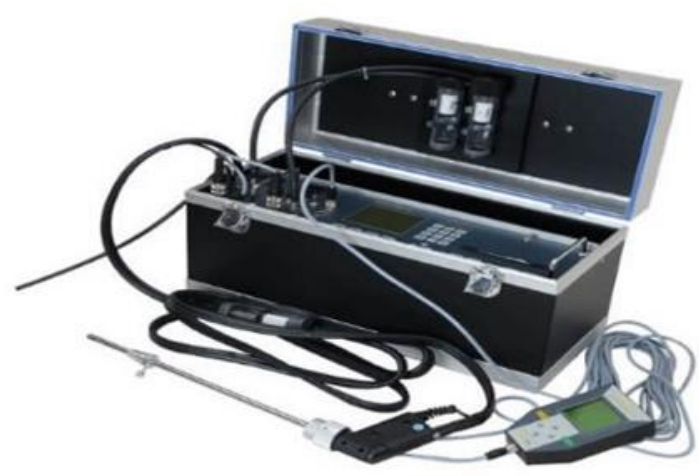

Fig. 3. Gas analyzer

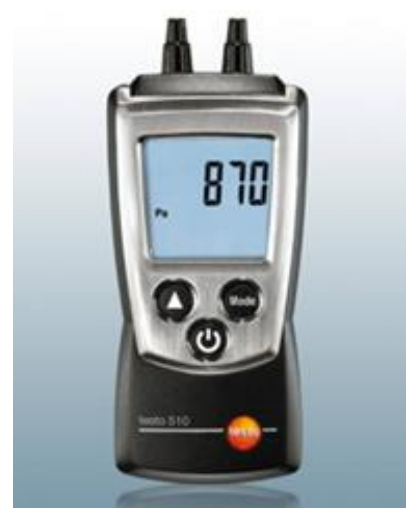

Fig. 4. Pressure differential measurement device

Chauvin Arnoux brand Energy Analyzer with serial number 140563JDH was used in the measurement of motor powers in order to calculate the energy consumption of the hotel where energy audit was conducted. The device measures in the standards of AB-0155-K and TS EN ISO / IEC 17025. For the flue gas analysis measurements in the hotel where the energy audit was carried out, measurements were made with the Madur brand, GA-21 PLUS model device with serial number 21294081. The device measures in accordance with TS EN ISOIEC 17025-2012 standards.

TESTO brand 510 model device with 38965918 serial number was used for pressure difference measurements in the hotel where energy audit was performed. The device measures in the standards of AB-0113-K and TS EN ISO / IEC 17025-2005.

Table 2. Technical specifications for three phase portable energy analyzer [16]

\begin{tabular}{lcc}
\hline Property & Unit & Value \\
\hline Internal Rechargeable Battery & $\mathrm{mAh}$ & 4000 \\
Full Charge Time & Hour & 5 \\
Size & HxWxL (cm) & $24 \times 18 \times 5.5$ \\
Weight & Gr & 1900 \\
Harmonic Measurement & Degree & 50 \\
Current, Voltage Measurement & Degree & 50 \\
Registration Memory & Gbyte & 8 \\
Language Option & Piece & 21 \\
\hline
\end{tabular}

Table 3. Technical specifications of gas analyzer specifications [17]

\begin{tabular}{lcc}
\hline Property & Unit & Value \\
\hline Size & Y x G x U (cm) & $4.6 \times \times 2.6 \times 24$ \\
\hline Weight & $\mathrm{Kg}$ & 6.2 \\
\hline Working Conditions & ${ }^{0} \mathrm{C}$ & 10 to 50 \\
\hline Storage Temperature & ${ }^{0} \mathrm{C}$ & 0 to 55 \\
\hline Power. Source & VAC & 90 to 240 \\
\hline Maximum Power & $\mathrm{W}$ & 70 \\
Consumption & $\begin{array}{c}\text { Type } \\
\text { Working Time } \\
\text { (hour) }\end{array}$ & Lead Acid \\
Battery & $\begin{array}{c}7 \\
\text { Charging Time } \\
\text { (hour) }\end{array}$ & 14 \\
\hline & $\begin{array}{c}\mathrm{kB} \\
\text { Number of Data } \\
\text { Sets }\end{array}$ & 1024 \\
\hline
\end{tabular}

The hotel business, whose energy audit was carried out, was built in 2006 and restoration work was carried out between 2015 and 2017. In the hotel, there are a total of 44 rooms including $20 \mathrm{~m}^{2}$ standard rooms, $25 \mathrm{~m}^{2}$ superior rooms, $30 \mathrm{~m}^{2}$ luxury rooms and $35 \mathrm{~m}^{2}$ suite rooms, and there is a lobby, a currency exchange office, a restaurant, a breakfast room, a cafe, a bar, a parking area and a garden. 
Table 4. Technical specifications for pressure differential meter [18]

\begin{tabular}{lcc}
\hline Property & Unit & Value \\
\hline Measuring Range & $\mathrm{hPa}$ & 0 to 100 \\
Resolution & $\mathrm{hPa}$ & 0.01 \\
Dimensions & $\mathrm{cm}$ & $11.9 \times 4.6 \times 2.5$ \\
Operating temperature & ${ }^{0} \mathrm{C}$ & 0 to 50 \\
Protection Class & & $\mathrm{IP} 40$ \\
Maximum Static Pressure & mbar & 500 \\
Measuring Speed & $\mathrm{s}$ & 0.5 \\
& Type & Mikro \\
Battery & Capacity & 2 \\
& (AAA) & 50 \\
Storage Temperature & Life (h) & 50 to 70 \\
\hline
\end{tabular}

Table 5. Features of the hotel business whose energy audit

\begin{tabular}{lcc}
\hline Specifications & Unit & Quantity \\
\hline Closed Volume & $\mathrm{m}^{3}$ & 3800 \\
Annual Heating Degree Days & ${ }^{0} \mathrm{C} /$ day & 1374 \\
Annual Cooling Degree Days & ${ }^{0}$ C/day & 349 \\
Heating / Cooling System & Two-Pipe Fan-Coil \\
Insulation Condition & Mold mortar-Plaster-Paint \\
\hline
\end{tabular}

\subsection{Investigation of energy consumption}

The monthly electricity consumption values of the hotel, whose energy audit was conducted, were converted from $\mathrm{kWh}$ to TEO unit, and the monthly natural gas consumption values were converted from $\mathrm{m}^{3}$ to TEO.

$$
\begin{aligned}
& \text { TOE }=0.000086 * k W h \\
& T O E=0.000825 * m^{3}
\end{aligned}
$$

According to the electricity data obtained, the least electricity consumption is seen in April, as the need for cooling is low due to climate conditions in April. The highest electricity consumption was in August. Considering the general table, it is observed that electricity consumption is higher in the hot summer months than in other months. Looking at the data for natural gas, the highest natural gas consumption was in December. December natural gas consumption is followed by January and February with similar consumption values. The reason is that the heating system is used more in winter than in other months.

Considering the general picture, it is observed that natural gas consumption is higher in the cold winter months than in other months. Natural gas is also used in the restaurant section in the hotel business. Since September coincides with the school opening period, the decrease in the number of customers in the hotel reduces the use of natural gas in the restaurant section. Therefore, the least natural gas consumption in the hotel business is in September.

\begin{tabular}{|c|c|c|c|c|c|c|}
\hline \multirow{4}{*}{ Months } & \multicolumn{3}{|c|}{ Electricity } & \multicolumn{3}{|c|}{ Natural gas } \\
\hline & \multirow{2}{*}{\multicolumn{2}{|c|}{$\begin{array}{c}\text { Consumption } \\
\text { Purchased }\end{array}$}} & Cost (TL) & Cons & & Cost (TL) \\
\hline & & & \multirow{2}{*}{ Total } & \multicolumn{2}{|c|}{ Purchased } & \multirow{2}{*}{ Total } \\
\hline & kWh & TOE & & $\mathbf{m}^{3}$ & TOE & \\
\hline January & 52674.42 & 4.53 & 24230.23 & 12230.30 & 10.09 & 14676.36 \\
\hline February & 55581.39 & 4.78 & 25567.43 & 12460.60 & 10.28 & 14952.72 \\
\hline March & 51162.79 & 4.40 & 23534.88 & 10933.33 & 9.02 & 13119.99 \\
\hline April & 40000 & 3.44 & 18400.00 & 10024.24 & 8.27 & 12029.08 \\
\hline May & 50930.23 & 4.38 & 23427.90 & 5660.60 & 4.67 & 6792.72 \\
\hline June & 90000 & 7.74 & 41400.00 & 3878.78 & 3.20 & 4654.53 \\
\hline July & 75813.95 & 6.52 & 34874.41 & 3709.09 & 3.06 & 4450.90 \\
\hline August & 92325.58 & 7.94 & 42469.76 & 3612.12 & 2.98 & 4334.54 \\
\hline September & 68139.53 & 5.86 & 31344.18 & 3490.90 & 2.88 & 4189.08 \\
\hline October & 57325.58 & 4.93 & 26369.76 & 6193.93 & 5.11 & 7432.71 \\
\hline November & 46511.62 & 4.00 & 21395.34 & 10193.93 & 8.41 & 12232.71 \\
\hline December & 48139.53 & 4.14 & 22144.18 & 12836.36 & 10.59 & 15403.63 \\
\hline Total & 728604.7 & 62.66 & 335158.13 & 95224.24 & 78.56 & 114269.08 \\
\hline
\end{tabular}

Table 6. Monthly electricity consumption and natural gas energy costs of the hotel management, who's energy audit 
Table 7. Monthly energy consumption and costs of the hotel management for which an energy audit was performed in 2019

\begin{tabular}{|l|c|c|c|c|}
\hline \multirow{2}{*}{ Months } & \multicolumn{3}{c}{ Total Energy Consumption } \\
\cline { 2 - 3 } & Electricity & Natural gas & \multirow{2}{*}{ Total } & \multirow{2}{*}{ Total Cost } \\
\cline { 2 - 3 } & Purchased & Purchased & & TL \\
\hline January & 4.53 & TOE & TOE & 38906.59 \\
\hline February & 4.78 & 10.09 & 14.62 & 40520.15 \\
\hline March & 4.40 & 10.28 & 15.06 & 36654.87 \\
\hline April & 3.44 & 8.02 & 13.42 & 30429.08 \\
\hline May & 4.38 & 4.67 & 11.71 & 30220.62 \\
\hline June & 7.74 & 3.20 & 10.94 & 46054.53 \\
\hline July & 6.52 & 3.06 & 9.58 & 39325.32 \\
\hline August & 7.94 & 2.98 & 10.92 & 46804.31 \\
\hline September & 5.86 & 2.88 & 8.74 & 35533.26 \\
\hline October & 4.93 & 5.11 & 10.04 & 33802.48 \\
\hline November & 4.00 & 8.41 & 12.41 & 33628.061 \\
\hline December & 4.14 & 10.59 & 14.73 & 37547.81 \\
\hline Total & 62.66 & 78.56 & 141.22 & 449427.22 \\
\hline
\end{tabular}

Total Electricity and Natural Gas Consumption in 2019

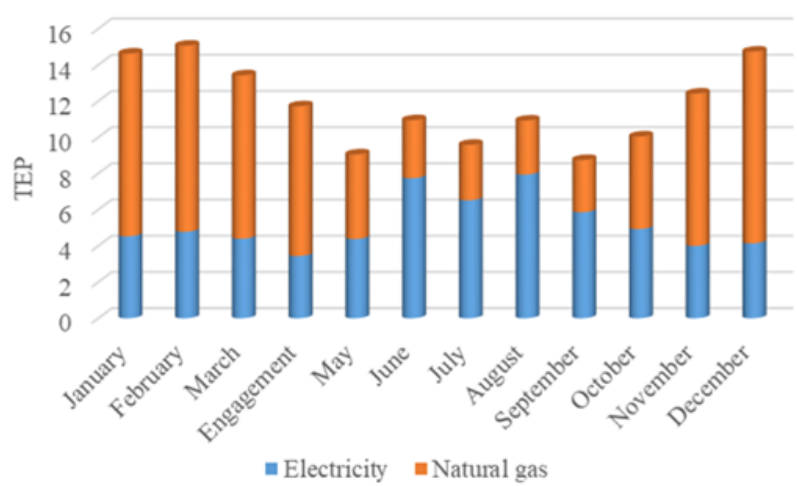

Fig. 5. Monthly electricity, natural gas and total energy consumption of the hotel management of which energy audit was made in 2019

\section{Research Findings and Discussion}

The hotel business, whose energy study is carried out, is a reinforced concrete building. The building consists of a ground floor, four mezzanines and a terrace. Reinforced concrete and aluminum joinery double glazing is used on the facade of the building. Large part of the building structure consists of glass areas. Polyvinyl Chloride (PVC) double glazing is used in the building structure. Heat losses of the building surface were measured with a thermal imager. Values between $+6.3{ }^{\circ} \mathrm{C}$ and $+22.6{ }^{\circ} \mathrm{C}$ were obtained on the building surface. There is more temperature transmission on the window sills compared to other surfaces.

\subsection{Heating system}

There are 1 floor type hot water boiler and 2 wall mounted condensing boilers in the hotel where the energy audit is carried out. Wall-mounted boilers are activated when the ambient air temperature drops below 0. Boilers are operated to meet the hot water need of the air handling unit, Fan-Coil units and domestic water. Surface insulation and flue gas analysis measurements were made in the boilers.

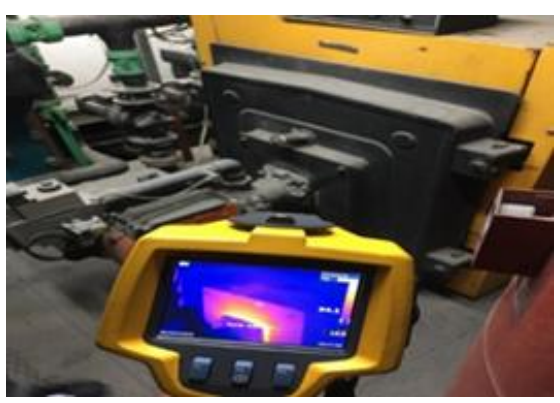

Fig. 7. Hot water boiler

Table 8. Thermal images of boiler surface at the hotel facility energy audit

\begin{tabular}{ccc}
\hline Measured & Unit & Quantity \\
\hline $\mathrm{CO}$ & $\mathrm{ppm}$ & 8 \\
$\mathrm{O}_{2}$ & $\%$ & 3.1 \\
$\mathrm{~T}$ & ${ }^{\circ} \mathrm{C}$ & 107 \\
$\mathrm{CO}_{2}$ & $\%$ & 3.05 \\
\hline
\end{tabular}



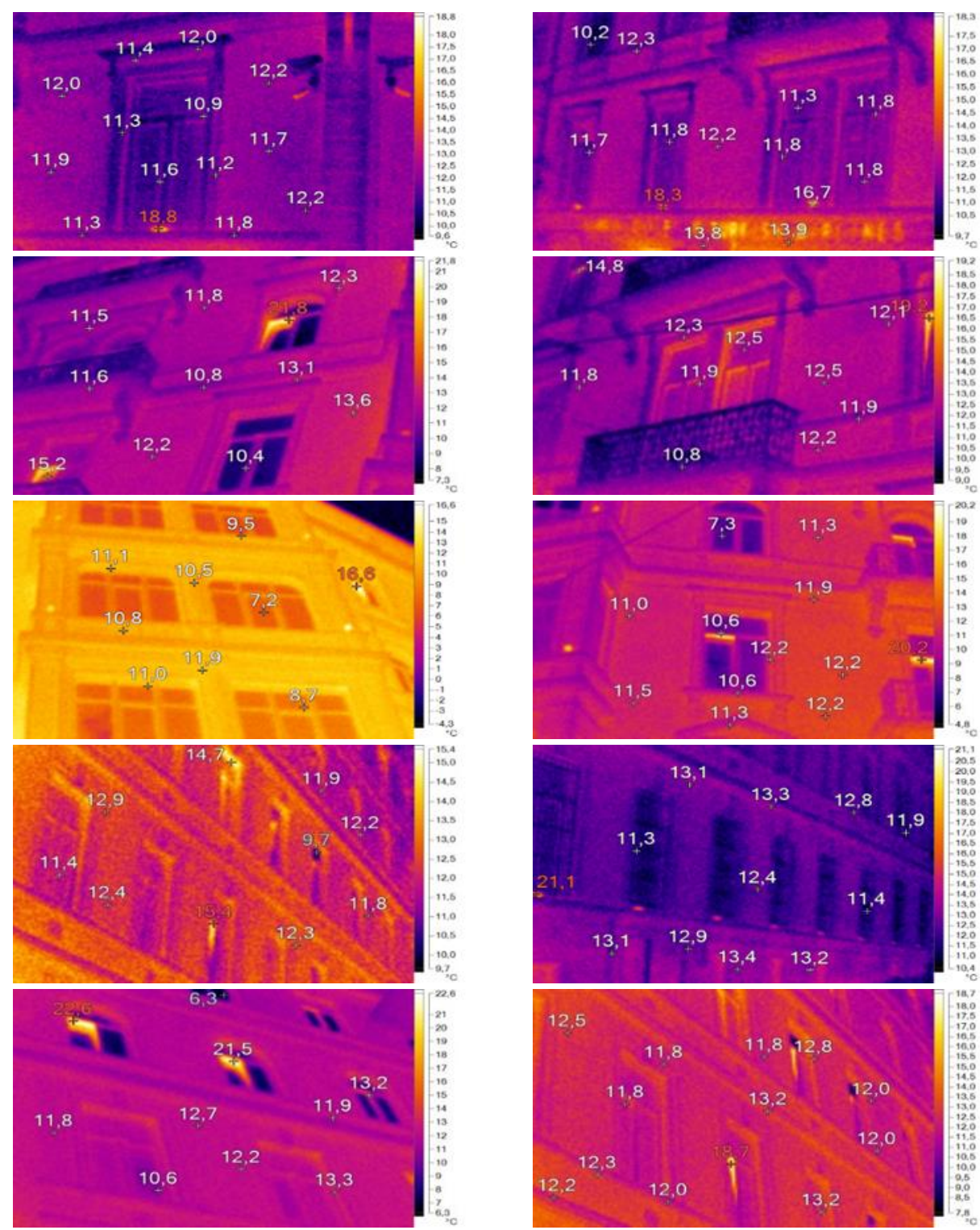

Fig. 6. Thermal images of the hotel management energy audit
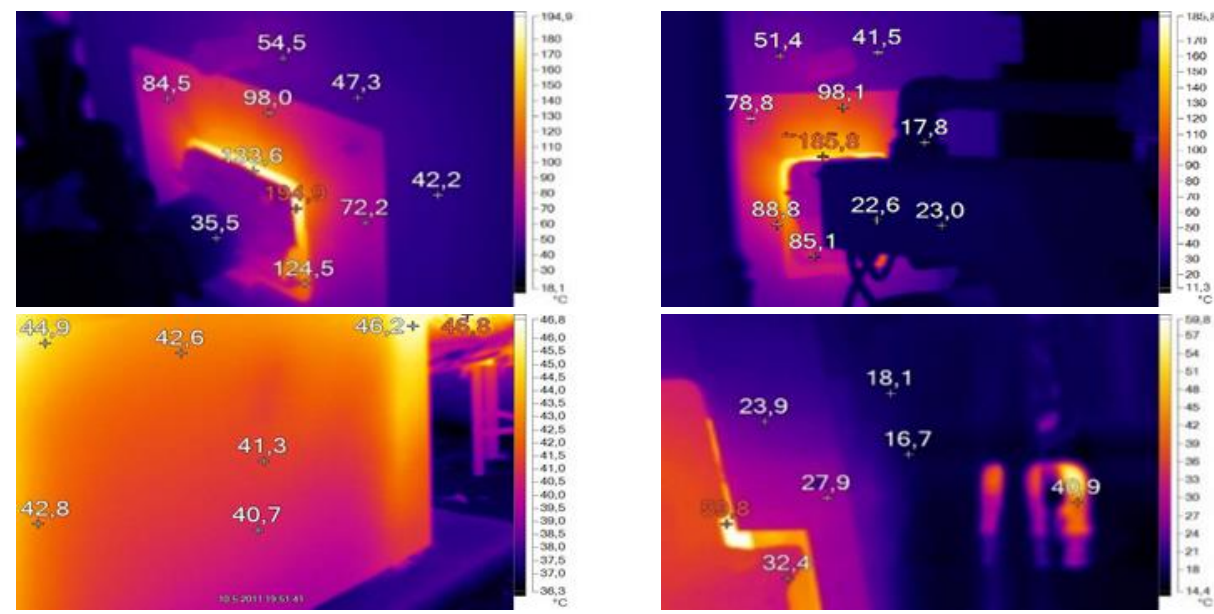

Fig. 8. Thermal images of boiler surface at the hotel facility energy audit 


\subsection{Air conditioning and ventilation systems}

There is 1 air handling unit and 1 exhaust aspirator as a ventilation system in the hotel where an energy study is conducted. In air conditioning, while the lobby is made with a variable refrigerant flow (VRF) system, the other floors and rooms are made with a Fan-Coil system. Fan-Coil units have two pipes.
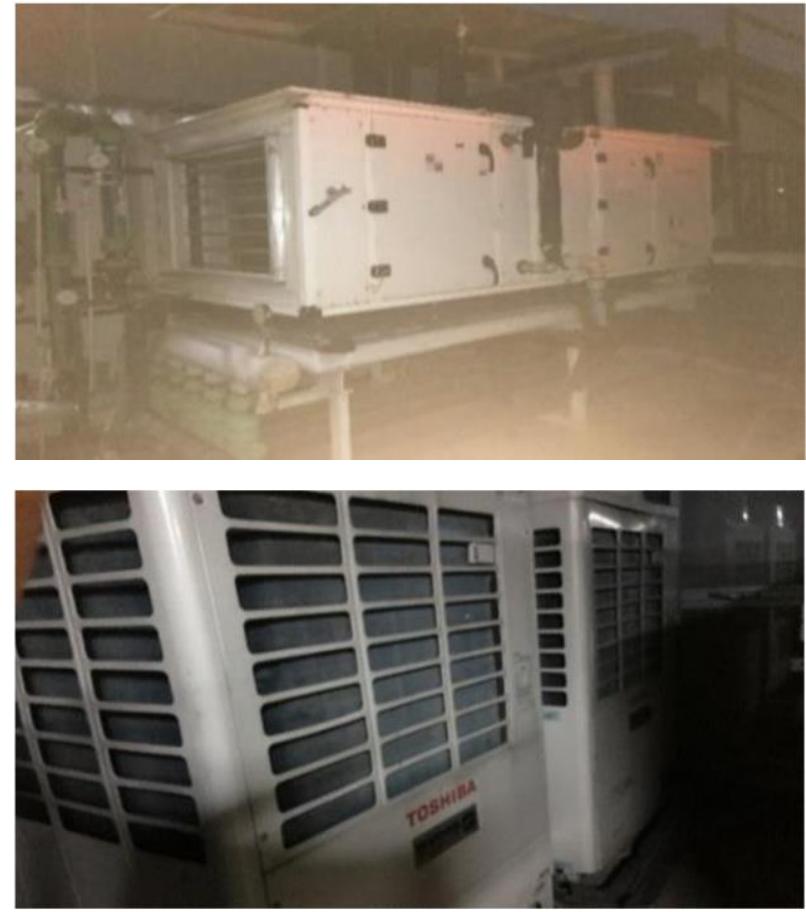

Fig. 9. Hotel enterprise ventilation and air conditioning units with energy audit

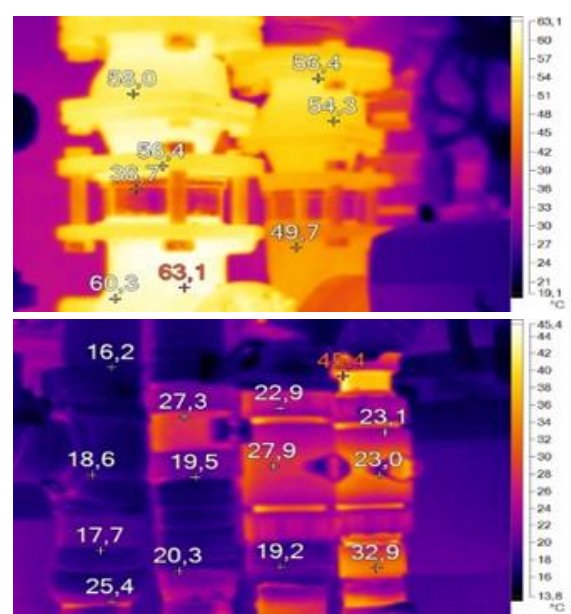

Fig. 11. Thermal views of non-insulated valves and equipment in a hotel facility energy audit
The motors used in the ventilation system have $\mathrm{EEF}_{2}$ efficiency. If motors with $\mathrm{IE}_{4}$ efficiency are used in this system, $15 \%$ energy efficiency is achieved.

\subsection{Cooling system}

There is one air cooled chiller with in the hotel business where energy study is carried out. Copper pipes with high heat conduction are called condensers. Air cooled chillers are devices that cool with the air in the condenser. With the fans on it, it cools the refrigerant flowing through the condenser.

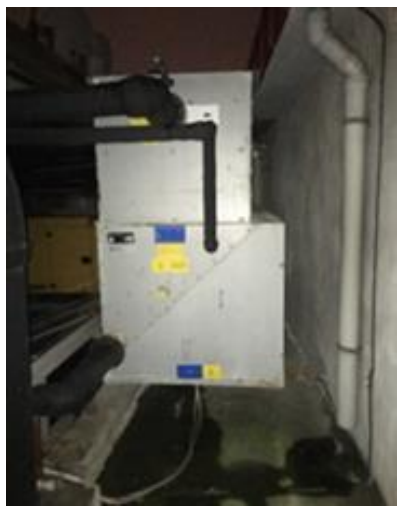

Fig. 10. Hotel facility chiller unit with an energy audit

\subsection{Installation}

During the survey, the uninsulated valves and equipment in the hot water transmission lines are generally in good condition. However, uninsulated valves and equipment have been found in some areas. An analysis was made for the insulation of the valves and flashes on the hot water line in the business.
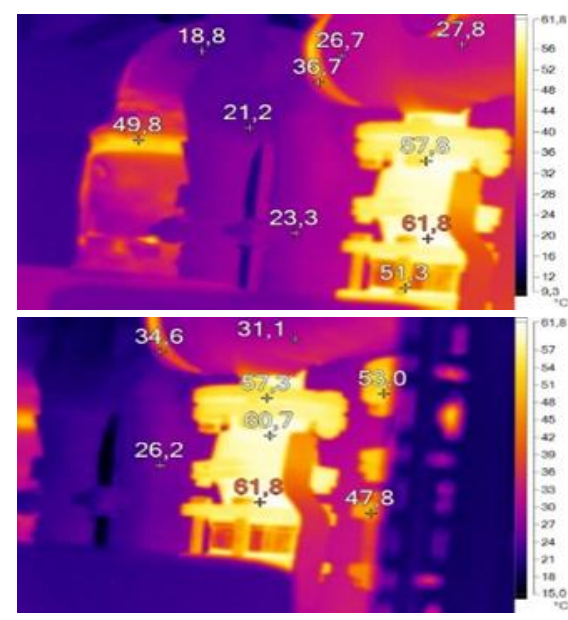

Example calculation for Line 1 in Table 9;

$$
\begin{aligned}
& \mathrm{U}_{c}=1,15 \times\left(T_{s}-T_{a} / d_{1}\right)^{0.25}=1,15 \times((65-10) / 0.1)^{0.25}=5,569 \mathrm{~W} / \mathrm{m}^{2} \mathrm{~K} \\
& U_{r}=5,67 \times 10^{-8} \times \mathrm{E} \times\left(T_{s}^{2}+T_{a}^{2}\right) x\left(T_{s}+T_{a}\right)=5,67 \times 10^{-8} \times 353,41 \times\left(65^{2}+10^{2}\right) \times(65+10)=6,5 \mathrm{~W} / \mathrm{m}^{2} \mathrm{~K} \\
& Q=\left(U_{c}+U_{r}\right) \times 2 \times \pi \times d_{1} \times\left(T_{s}-T_{a}\right)=(5.569+6.5) \times 2 \times 3.14 \times 0.1 \times(65-10)=416,866 \mathrm{Kcal} / \mathrm{h}
\end{aligned}
$$


Table 9. Energy consumption and cost of an uninsulated installation in a hotel with an energy audit

\begin{tabular}{lccccc}
\hline No & $\mathbf{1}$ & $\mathbf{2}$ & $\mathbf{3}$ & $\mathbf{4}$ & $\mathbf{5}$ \\
\hline Site Name & Hot water line & Hot water line & Hot water line & Hot water line & Hot water line \\
$\mathbf{d}_{\mathbf{1}}(\mathbf{m})$ & 0.1 & 0.065 & 0.05 & 0.04 & 0.032 \\
$\mathbf{T s}\left({ }^{\circ} \mathbf{C}\right)$ & 65 & 65 & 65 & 65 & 65 \\
$\left.\mathbf{T}_{\mathbf{a}}{ }^{\circ} \mathbf{C}\right)$ & 10 & 10 & 10 & 10 & 10 \\
$\mathbf{U c}\left(\mathbf{W} / \mathbf{m}^{2} \mathbf{K}\right)$ & 5.569 & 6.202 & 6.623 & 7.003 & 7.405 \\
$\mathbf{U r}\left(\mathbf{W} / \mathbf{m}^{2} \mathbf{K}\right)$ & 6.5 & 6.5 & 6.5 & 6.5 & 6.5 \\
$\mathbf{Q}(\mathbf{K c a l} / \mathbf{h})$ & 416.866 & 285.18 & 226.63 & 186.554 & 153.688 \\
$\mathbf{E}$ & 353.41 & 353.41 & 353.41 & 353.41 & 353.41 \\
\hline
\end{tabular}

Heat loss after insulation;

$$
\begin{aligned}
Q_{\text {ins }}=\left(\pi x\left(T_{s}-T_{a}\right)\right) /\left[\left(L_{n} \times d_{2} / d_{1}\right) / 2 \times \lambda\right]+\left[1 /\left(U_{\text {so }} \times d_{2}\right)\right] \\
Q_{\text {ins }}=(3.14 \times(65-10)) /[(4 x(0.2 / 0.1)) / 2 \times 1.6]+[1 /(30.5 \times 0.2)]=69,24 \mathrm{Kcal} / \mathrm{h}
\end{aligned}
$$

Table 10. Insulated installation energy consumption and cost of the hotel enterprise whose energy audit was performed

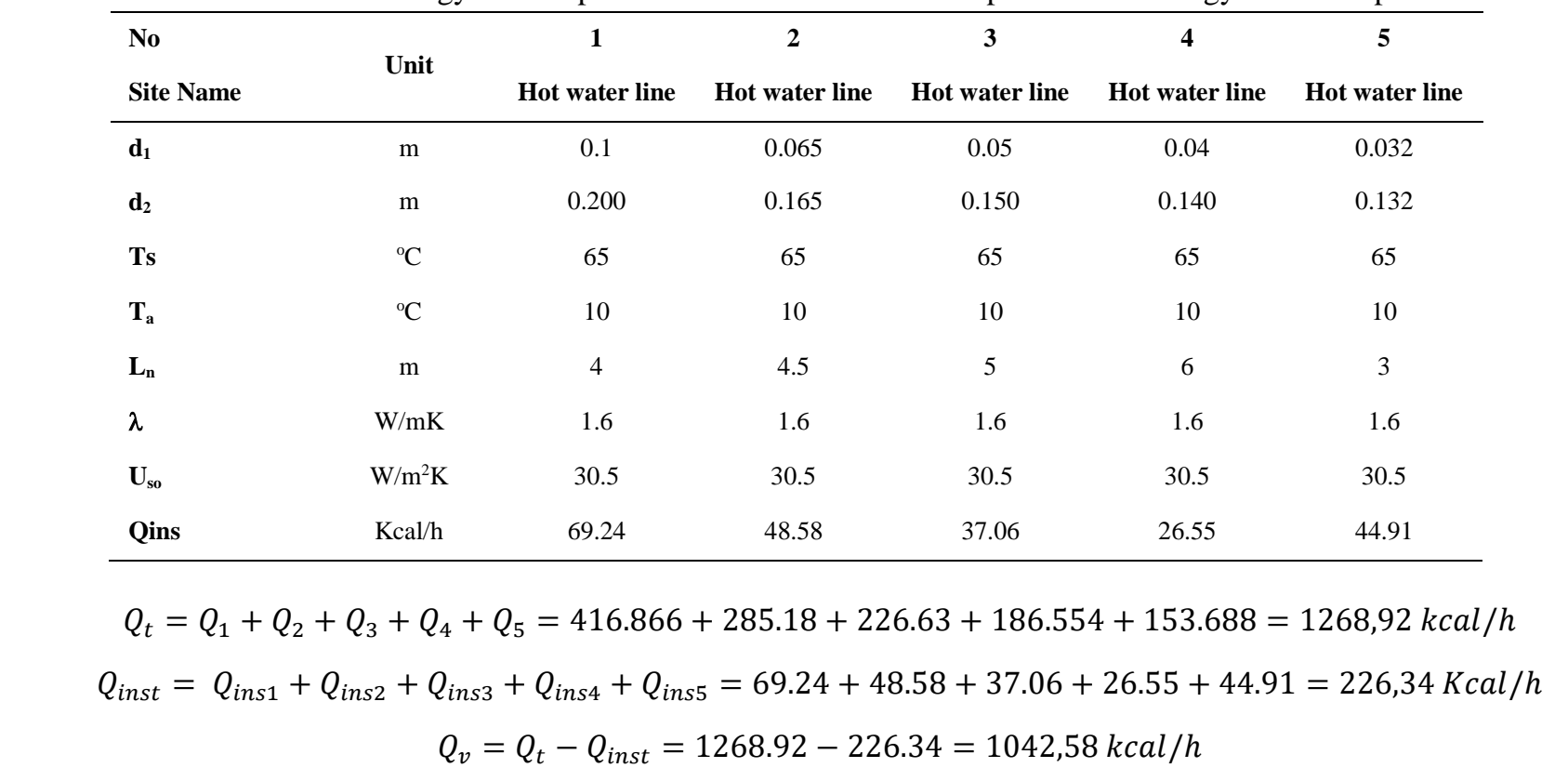

Annual Fuel Savings $=Q_{-} v x\left(((h * y l l)) /\left(\left(H_{-}(u) \times n\right)\right)\right)=1042.58 \times(((24 * 200)) /((8250 \times 0.9)))=673,991 \mathrm{m3} / y e a r$

After the insulation, there is a decrease in consumption of approximately $17 \%$ per year.

\subsection{Electricity distribution system}

There is a main distribution switch with a power of 630 amperes in the hotel where the energy study is carried out. The switch with 630 ampere power is supported and works with a 12-step compensation system. Current, voltage, pf, power and harmonic values were obtained with the analyzer connected to the main distribution switch.

The single term single time industrial low voltage (LV) tariff is used in the hotel business where an energy study is conducted. For the tariff analysis, the bills for the last one year were examined. When the bills were examined, it was seen that the general use was generally during the daytime. Since most of the electricity in the facility is used in the daytime tariff, it can be said that the current single term tariff is a more appropriate tariff.

As a result of the measurements, it can be said that the harmonic values are at normal levels. Considering the load distributions, it was seen that it was distributed evenly. The pf value was measured to be close to 1 , and it can be said that this value is good. 


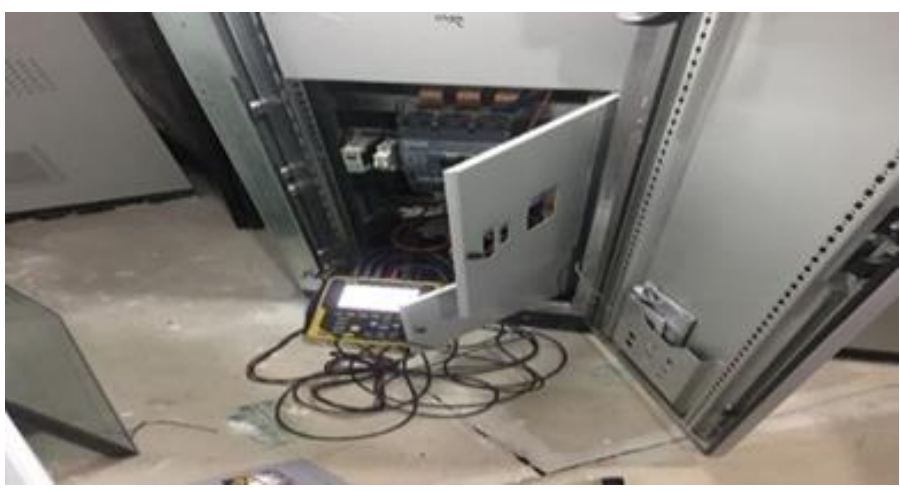

Fig. 12. Hotel management main distribution (ADP) panel with energy audit
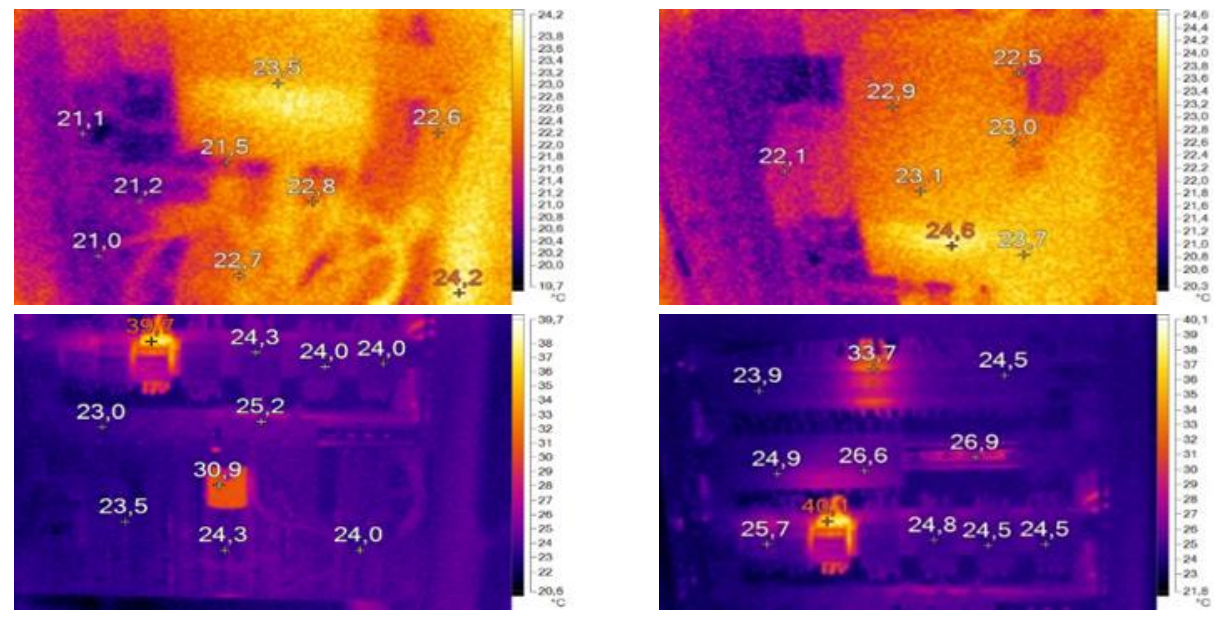

Fig. 13. Thermal view of the hotel management main distribution board for an energy audit

\subsection{Electric motors}

There are heating, cooling, hydrophore and fire pump motors as electric motors in the hotel where the energy study is carried out. The efficiency classes of existing motors are $\mathrm{EFF}_{2}$ and $\mathrm{IE}_{1}$. Replacing low efficiency motors with high efficiency motors will save energy. The efficiency of the electric motors recommended to be replaced is included in the standard efficiency of $\mathrm{EFF}_{2}$ and $\mathrm{IE}_{1}$ class. It is recommended to replace them with premium efficiency $\left(\mathrm{IE}_{4}\right)$ class motors. When the engine savings analysis was made in the business where energy audit was performed, the investment payback period was calculated.

Example calculation for Heating Circulation Pump in Table 11;

Current Engine Load Rate = Measured Power $/$ Plate Strength $=2.8 / 3=\%$ 93,33

Mechanical Power Used $=$ Recommended Power * Current Motor Efficiency =2,8*0,8333 = 2,33 $\mathrm{kW}$

Power Taken After Replacement $=$ Recommended Power $*$ New Motor Efficiency $=2.8 * 0.90=2.52$

Amount of Savings = Measured Power - Power Taken After Change $=2.8-2.52=0.28$

Annual Electricity Savings = Savings Amount $x$ Hour $x$ Year $=0.28 \times 12 \times 365=1226.4 \mathrm{kWh}$
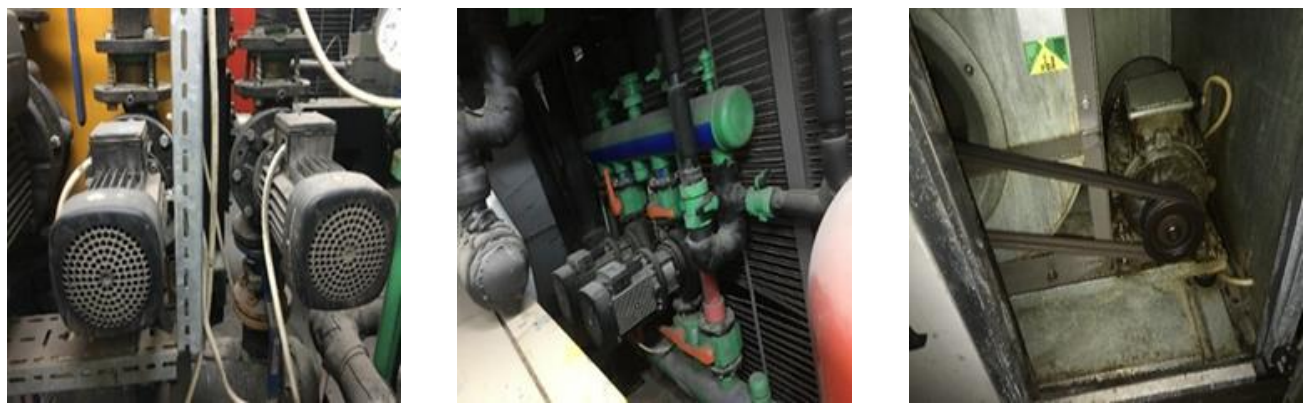

Fig. 14. Electrical motors of the hotel management with an energy audit 
Table 11. Motor saving analysis for the proposed change in the hotel business whose energy audit was made

\begin{tabular}{|c|c|c|c|c|c|c|}
\hline No & & $\mathbf{M}_{1}$ & $\mathbf{M}_{2}$ & $\mathbf{M}_{3}$ & $\mathbf{M}_{4}$ & $\mathbf{M}_{5}$ \\
\hline Information & Unit & $\begin{array}{c}\text { Heating } \\
\text { circulation } \\
\text { pump }\end{array}$ & $\begin{array}{c}\text { Fan Coil } \\
\text { Heating } \\
\text { circulation } \\
\text { pump }\end{array}$ & $\begin{array}{c}\text { Fan Coil } \\
\text { Cooling } \\
\text { circulation } \\
\text { pump }\end{array}$ & $\begin{array}{l}\text { Heating } \\
\text { fan motor }\end{array}$ & $\begin{array}{l}\text { Aspirator } \\
\text { fan motor }\end{array}$ \\
\hline $\begin{array}{l}\text { Current Measured } \\
\text { Powers }\end{array}$ & $\mathrm{kW}$ & 2.8 & 2.9 & 2.6 & 3.2 & 2.4 \\
\hline Available Plate Powers & $\mathrm{kW}$ & 3 & 3 & 3 & 4 & 3 \\
\hline $\begin{array}{l}\text { Available Motor } \\
\text { Efficiencies }\end{array}$ & $\%$ & 83.1 & 83.1 & 83.1 & 84.7 & 83.1 \\
\hline Current Load Rate & $\%$ & 93.33 & 96.67 & 86.67 & 80.00 & 80.00 \\
\hline Mechanical Power Used & $\mathrm{kW}$ & 2.33 & 2.41 & 2.16 & 2.71 & 1.99 \\
\hline $\begin{array}{l}\text { Recommended Engine } \\
\text { Power }\end{array}$ & $\mathrm{kW}$ & 1.1 & 1.5 & 2.2 & 3 & 4 \\
\hline New Engine Efficiency & $\%$ & 90,00 & 90,00 & 90,00 & 90,90 & 90,00 \\
\hline $\begin{array}{l}\text { Power Taken After } \\
\text { Change }\end{array}$ & $\mathrm{kW}$ & 2.52 & 2.61 & 2.34 & 2.91 & 2.16 \\
\hline Unit price & TL & 0.46 & 0.46 & 0.46 & 0.46 & 0.46 \\
\hline $\begin{array}{l}\text { Annual Electricity. } \\
\text { Saving }\end{array}$ & $\mathrm{kWh}$ & 1226.4 & 1270.2 & 1138.8 & 1270.2 & 1051.2 \\
\hline Annual Money Savings & $\mathrm{TL}$ & 564.144 & 584.292 & 523.848 & 584.292 & 483.552 \\
\hline Investment Cost & TL & 781.00 & 781.00 & 781.00 & 1104.50 & 781.00 \\
\hline Payback Period & Year & 1.38 & 1.33 & 1.49 & 1.89 & 1.61 \\
\hline
\end{tabular}

\subsection{Lighting}

Low-efficiency light bulbs were used in the hotel where energy study was conducted, and $100 \%$ energy savings were

achieved by replacing the bulbs with LED-efficient luminaires.

Table 12. Fixtures recommended for replacement for the hotel whose energy audit

\begin{tabular}{|c|c|c|c|c|c|}
\hline No & & 1 & 2 & 3 & 4 \\
\hline Info & Unit & Floors & $\begin{array}{l}\text { Boiler } \\
\text { Room }\end{array}$ & Basement & $\begin{array}{c}\text { Basement } \\
\text { Office }\end{array}$ \\
\hline Current Armature Power & $\mathrm{W}$ & $40 \mathrm{~W}$ & $72 \mathrm{~W}$ & $36 \mathrm{~W}$ & $36 \mathrm{~W}$ \\
\hline $\begin{array}{l}\text { Recommended Fixture } \\
\text { Power }\end{array}$ & $\mathrm{W}$ & $20 \mathrm{~W}$ & $36 \mathrm{~W}$ & $18 \mathrm{~W}$ & $18 \mathrm{~W}$ \\
\hline $\begin{array}{l}\text { Energy Consumption of } \\
\text { Current Luminaire per } \\
\text { Year }\end{array}$ & kWh/year & 34689.6 & 1681.92 & 525.6 & 1419.12 \\
\hline $\begin{array}{l}\text { Energy Consumption of the } \\
\text { Recommended Luminaire } \\
\text { per Year }\end{array}$ & kWh/year & 17344.8 & 840.96 & 262.8 & 709.56 \\
\hline Unit Investment Cost & $\mathrm{TL}$ & 50 & 180 & 90 & 90 \\
\hline Total Investment Cost & $\mathrm{TL}$ & 6600 & 1440 & 450 & 540 \\
\hline Annual Energy Savings & $\mathrm{kWh} /$ year & 17344.8 & 840.96 & 262.8 & 709.56 \\
\hline Annual Energy Savings & $\mathrm{TL}$ & 7978.6 & 386.84 & 120.88 & 326.39 \\
\hline Payback Period & year & 0.82 & 3.7 & 3.7 & 1.65 \\
\hline
\end{tabular}




$$
1 \mathrm{~kW} / \mathrm{h}=1000 \mathrm{~W} / \mathrm{h}
$$

For example, changing a 40 Watt Incandescent crystal bulb with E27 base Osakalight 20W bulb;

$$
40 \mathrm{~W} / \mathrm{h}=0.04 \mathrm{~kW} / \mathrm{h}
$$

$$
\text { Energy Consumed by the Light Bulb in a Day = Light Bulb Power } * \text { Hours Worked in a Day }
$$$$
\text { Energy Consumed by the Light Bulb in a Day }=0.04 * 18=0.72 \mathrm{~kW}
$$

There are 13240 Watt Incandescent crystal bulbs in total in the 1st floor, 2nd floor, 3rd floor, 4th and 5th floors.

\begin{tabular}{|c|c|c|c|c|c|c|}
\hline \multicolumn{7}{|c|}{ Total energy expended in a year $=132 * 0.36 * 365=17344,8 \mathrm{~kW} /$ year } \\
\hline Locus & Fixture Type & $\begin{array}{l}\text { Recommended } \\
\text { Fixture Type }\end{array}$ & $\begin{array}{l}\text { Luminaire } \\
\text { Power (W) }\end{array}$ & $\begin{array}{c}\text { New } \\
\text { Luminaire } \\
\text { Power }(W)\end{array}$ & $\begin{array}{c}\text { Daily } \\
\text { Working } \\
\text { Time (hour) }\end{array}$ & Piece \\
\hline Ground floor & $\begin{array}{l}40 \mathrm{~W} \text { Incandescent } \\
\text { crystal bulb }\end{array}$ & $\begin{array}{l}\text { 20W Osakalight } \\
\text { bulb with E27 } \\
\text { socket }\end{array}$ & 40 & 20 & 18 & 32 \\
\hline 1 Floor & $\begin{array}{l}40 \text { W Incandescent } \\
\text { crystal bulb }\end{array}$ & $\begin{array}{l}\text { 20W Osakalight } \\
\text { bulb with E27 } \\
\text { socket }\end{array}$ & 40 & 20 & 18 & 20 \\
\hline 2 floors & $\begin{array}{l}40 \text { W Incandescent } \\
\text { crystal bulb }\end{array}$ & $\begin{array}{l}\text { 20W Osakalight } \\
\text { bulb with E27 } \\
\text { socket }\end{array}$ & 40 & 20 & 18 & 20 \\
\hline 3 floor & $\begin{array}{l}40 \mathrm{~W} \text { Incandescent } \\
\text { crystal bulb }\end{array}$ & $\begin{array}{l}\text { 20W Osakalight } \\
\text { bulb with E27 } \\
\text { socket }\end{array}$ & 40 & 20 & 18 & 20 \\
\hline 4th floor & $\begin{array}{l}40 \text { W Incandescent } \\
\text { crystal bulb }\end{array}$ & $\begin{array}{l}\text { 20W Osakalight } \\
\text { bulb with E27 } \\
\text { socket }\end{array}$ & 40 & 20 & 18 & 20 \\
\hline 5 th floor & $\begin{array}{l}40 \mathrm{~W} \text { Incandescent } \\
\text { crystal bulb }\end{array}$ & $\begin{array}{l}\text { 20W Osakalight } \\
\text { bulb with E27 } \\
\text { socket }\end{array}$ & 40 & 20 & 18 & 20 \\
\hline Boiler Room & $\begin{array}{l}2 \times 36 \mathrm{~W} \text { T8 } \\
\text { luminaire }\end{array}$ & $\begin{array}{l}2 \times 18 \mathrm{~W} \text { T8 } \\
\text { luminaire }\end{array}$ & 72 & 36 & 8 & 8 \\
\hline Basement & $\begin{array}{l}\text { 1x } 36 \mathrm{~W} \text { T8 } \\
\text { luminaire }\end{array}$ & $\begin{array}{l}\text { 1x 18W T8 } \\
\text { luminaire }\end{array}$ & 36 & 18 & 8 & 5 \\
\hline $\begin{array}{l}\text { Basement } \\
\text { Floor Office }\end{array}$ & $\begin{array}{l}\text { 1x 36W T8 } \\
\text { luminaire }\end{array}$ & $\begin{array}{l}\text { 1x } 18 \mathrm{~W} \text { T8 } \\
\text { luminaire }\end{array}$ & 36 & 18 & 18 & 6 \\
\hline
\end{tabular}

$$
\begin{aligned}
& \text { Total energy spent in a year }=\text { Number of bulbs } * \text { Power consumed in a day * year } \\
& \text { Total energy spent in a year }=132 * 0.72 * 365=34689.6 \mathrm{~kW} / \text { year }
\end{aligned}
$$

The power to be consumed by the recommended 20 Watt bulb per day;

\section{Conclusions}

In this study, the energy consumption and improvement of consumption values of the hotel business in 2019, whose energy study was conducted, was examined. As a result of the energy study, the business was evaluated in terms of energy management, and priority savings projects were investigated according to the results of the measurements and calculations.

- The heat losses of the building surface of the hotel were measured with a thermal camera. Values between $+6.3^{\circ} \mathrm{C}$ and $+22.6{ }^{\circ} \mathrm{C}$ were obtained on the building surface. 
There is more temperature transition on the window sills compared to other surfaces.

- Using the boiler efficiency and flue gas measuring device, $3.1 \%$ oxygen and $107{ }^{\circ} \mathrm{C}$ flue gas temperature was determined in the flue gas. Losses are examined according to the determined values. In this case, according to the measurements, it can be said that the combustion efficiency is good when the hot water boilers of the hotel where the energy study is performed are examined.

- The motors used in the ventilation system have $\mathrm{EEF}_{2}$ efficiency. If motors with $\mathrm{IE}_{4}$ efficiency are used in this system, $15 \%$ energy efficiency will be achieved.

- When the insulation recommended for the valves and flashes on the hot water installation line in the facility is evaluated, it is seen that the annual consumption is reduced by approximately $17 \%$ after the insulation is made. The investment payback period will be within 2,47 years.

- The single term single time industrial low voltage (LV) tariff is used in the hotel business where an energy study is conducted. For the tariff analysis, the bills for the last one year were examined. When the bill was examined, it was seen that the general use was generally during daylight hours. Since most of the electricity in the facility is used in the daytime tariff, it can be said that the current single term tariff is a more appropriate tariff.

- As a result of the main distribution panel measurements, it can be said that the harmonic values are at normal levels. Considering the load distributions, it is seen that it is evenly distributed. The pf value was measured to be close to 1 , and it can be said that this value is good.

- After heating, booster and fire pump motors with efficiency class $\mathrm{EFF}_{2}$ were replaced with IE4 efficiency motors, it is seen there is a $6.9 \%$ increase in motor efficiency. As a result of replacing the $\mathrm{IE}_{1}$ class engine used in the cooling system with an IE4 class engine, the engine efficiency is expected to increase by $6.2 \%$.

As a result of the analysis of the luminaires recommended to be changed in the business, the total annual electricity savings were determined as $19158.12 \mathrm{~kW} /$ year. The investment payback period will be within 2.46 years in average.

\section{Acknowledgment}

This study is prepared as a part of Fatma Nur GÜNAY's MS Thesis. (Advisor: Dr. Fatih AYDIN).

\section{$\underline{\text { ORCID }}$}

F. Aydin

0000-0003-4828-0649

F. N. Günay

$0000-0002-4600-5216$

\begin{tabular}{|ll|}
\hline \multicolumn{2}{|l|}{ Nomenclature } \\
$\%$ & Percent \\
$\mathrm{ADP}$ & Main Distribution Board \\
$\mathrm{BTU}$ & British Unit System \\
${ }^{\circ} \mathrm{C}$ & Degree \\
$\mathrm{Cal}$ & Calories \\
$\mathrm{CO}$ & Carbon Monoxide \\
$\mathrm{CO}_{2}$ & Carbon Dioxide \\
$\mathrm{EFF}_{1}$ & First Class Improved Engine \\
$\mathrm{EFF}_{2}$ & Second Class Improved Engine \\
${ }^{\circ} \mathrm{F}$ & Fahrenheit \\
$\mathrm{IE}_{1}$ & Standard Efficiency (EFF \\
$\mathrm{IE}_{2}$ & High Efficiency (EFF ${ }_{1}$ According \\
$\mathrm{IE}_{3}$ & Very High Efficiency \\
$\mathrm{IE}_{4}$ & Super High Efficiency \\
$\mathrm{J}$ & Joule \\
$\mathrm{kcal} / \mathrm{h}$ & Kilocalorie / Hour \\
$\mathrm{kWh}$ & Kilowatt-Hour \\
$\mathrm{LV}$ & Low Voltage \\
$\mathrm{m}^{3}$ & Cubic Meter \\
$\mathrm{O}_{2}$ & Oxygen Gas \\
$\mathrm{Pf}$ & Power Factor \\
$\mathrm{ppm}$ & Parts Per Million \\
$\mathrm{PVC}_{\mathrm{SI}}$ & Polyvinyl Chloride \\
$\mathrm{SI}_{\mathrm{T}}$ & International System Of Units \\
$\mathrm{TOE}_{\mathrm{TL}}$ & Tone \\
$\mathrm{TRF}$ & Ton Equivalent Oil \\
$\mathrm{W}$ & Variable Refrigerant Flow \\
$\mathrm{W} / \mathrm{m}^{2} \mathrm{~K}$ & Watt \\
& Heat Transfer Coefficient \\
\hline & \\
\hline
\end{tabular}

\section{References}

[1] Kiyılmaz, M. B., 2019, Principles of energy management in industry and investigation of energy efficiency, Master Thesis, Muğla Sitk1 Kocaman University, Institute of Science, Muğla, 2-3.

[2] Karluk, S. R., 2007, Structural Transformation of the Turkish Economy of the Republic of Turkey Today, Page 239, Beta Bookstore, 11. Printing, ISBN: 9786053331858, İstanbul.

[3] Gezer, E. S., 2019, Energy efficiency of elevators, Master Thesis, Karabük University, Institute of Science, Karabük, 35-36. 
[4] Kavak, K., 2005, Energy Efficiency in Turkey and the world and Investigation of Turkish Industrial Energy Efficiency, State Planning Organization, Publication No DPT: 2689, Pages 2-40, Ankara.

[5] Yaşar, N., 2011, Within the context of municipal energy policies efficiency of energy in buildings sample of Isparta, Master Thesis, Süleyman Demirel University, Institute of Social Sciences, Isparta, 9-94.

[6] Şenol, M. A., 2011, Turkey Evaluation of the Potential Energy Efficiency, Ministry of Energy and Natural Resources, 2nd National Energy Efficiency Forum, Ankara, Turkey.

[7] Tuncer, T., 2012, Energy efficiency in buildings and according to degree day regions of determination of optimum insulation thickness with different materials, Master Thesis, Dokuz Eylül University, Institute of Science, İzmir, 13-14.

[8] Aksüzek, Y., 2003, Energy productivity and energy economy in complexs building, Master Thesis, Süleyman Demirel University, Institute of Science, Isparta, 1-3.

[9] Ascione, F., Bianco, N., Mauro, G.M. and Napolitano, D.F., 2019, Building envelope design: multi-objective optimization to minimize energy consumption, global cost and thermal discomfort. Application to different Italian climatic zones, Energy, Volume 174, Pages 359374.

[10] Belussi, L., Barozzi, B., Bellazzi, A., Danza, L., Devitofrancesco, A., Fanciulli, C., Scamoni, F., 2019, A review of performance of zero energy buildings and energy efficiency solutions, Journal of Building Engineering, Volume 25, 100772.

[11] Nazi, W.I.W.M., Royapoor, M., Wang,Y. and Roskilly, A.P., 2017, Office Building Cooling Load Reduction Using Thermal Analysis Method - A Case Study. Applied Energy, Volume 185, Part 2, Pages 1574-1584.

[12] Cheung H., Langner M.R. and Braun J.E., 2020, "Methodology to assess "no-touch" building audit software using simulated utility data" Science and Technology for the Built Environment, Doi Number: 10.1080/23744731.2020.1732160, pp.1-15.

[13] Hwang D.K., Cho J. and Moon J., 2019, "Feasibility study on energy audit and data driven analysis procedure for building energy efficiency: benchmarking in Korean hospital buildings", Energies, 12, 3006, Doi number: 10.3390/en12153006.

[14] Balan K.N. and Yashvanth U., 2020, "Energy audit in residential building - replacement of portable air conditioner by an energy efficient centralized air conditioner", International Journal of Ambient Energy, 41:2, 179-182.

[15] Fluke, 2009, Fluke Thermal Imager, PN 3433221, July 2009, Rev.1,5/11, USA.

[16] Chauvin Arnoux, 2013, Three-Phase Electrical Networks Analyser, Code 694286A02 France.
[17] Madur, 2019, Portable Gas Analyser GA-21 Plus, Zgierz/ Poland.

[18] Testo, 2017, Differential Pressure Measuring Device, https://www.testo.com/tr-TR/testo-510-set/p/05630510, Germany. 